\title{
Response of Forage Species Seeded for Mule Deer in Western Juniper Types of South- central Oregon
}

\author{
DONAVIN A. LECKENBY AND DALE E. TOWEILL
}

\begin{abstract}
Mule deer and livestock forage supplies were increased by seeding 11 species of grasses, forbs, and shrubs within chained and nonchained western juniper thermal cover stands in south-central Oregon. Standard crested wheatgrass and Siberian wheatgrass were the only species that established in significant amounts. Wheatgrass densities were greater in chain-drill treatments than in drill-only treatments. Among all experimental units, differences in emergence and establishment (plants $/ \mathrm{m}^{2}$ ) were greater than were differences in seeding rates (viable seeds $/ \mathrm{m}^{2}$ ). Standard crested wheatgrass density exceeded that of Siberian wheatgrass over both treatments and six pretreatment vegetation subtypes. Emergence of seedlings and establishment of wheatgrass were all significantly related to subtype. The chain-drill treatment produced more spring forage than did the drill-only treatment. Neither treatment provided more winter forage.
\end{abstract}

Decadence of forage plants in western juniper (Juniperus occidentalis $)^{1}$ stands prompted range and wildlife managers to initiate cooperative range rehabilitation programs in the arid northwest around 1960. Specific projects were designed to improve forage supplies for livestock and mule deer and yet maintain some cover on winter range by selective control of undesirable trees and shrubs followed by seeding of forage grasses, forbs, and browse. About 19,400 ha of western juniper were mechanically manipulated in central Oregon between 1964 and 1977 (Winegar and Elmore 1978). Of this amount, chaining was the method used to simultaneously uproot junipers and shrubs and prepare a seedbed in which forage species were planted on about 3100 ha.

Objectives of this study were as follows: (1) to document seedling emergence and plant establishment over time, (2) describe responses to chaining and drilling with drilling only treatments, (3) document which forage species survived, and (4) to determine if cmergence and establishment varied among pretreatment plant communities.

\section{Study Area}

The study was located in south-central Oregon near the northwestern corner of Lake County. It encompassed the Ward Lake grazing allotment, a 5033-ha portion of the Fork Rock deer herd winter range, about $6.4 \mathrm{~km}$ west of the town of Silver Lake. The area averaged about $1554 \mathrm{~m}$ in elevation along its broad western edge and about $1372 \mathrm{~m}$ in elevation along the southern edge.

\footnotetext{
Authors are respectively, biologist, Oregon Department of Fish and Wildlife, Research and Development Station. La Grande, and graduate research assistant, Department of Fisheries and Wildlife, Oregon State University, Corvallis.

The research was financed by Federal Aid to Wildlife Restoration funds under Oregon Project W-70-R.

The authors thank the following personnel for their part in the research: from the Oregon Department of Fish and Wildlife, A. Adams, L. Bright, B. Ferry, F. Grogan, N. Hartmann, M. Langdon, W. Lightfoot, V. Masson, L. Mathisen, M. Montgomery, A. Polenz, R. Roberts, D. Sanford, H. Winegar; from the Bureau of Land Management, E. Depaoli, L. Doughty, D. Getty, D. Gipe, M. LeNoue, D. Luman; and from Oregon State University, W.H.C. Schallig and W. Pyott.

Manuscript received October 13, 1980.
}

Plant names follow Garrison et al. (1976).
Shallow $(38 \mathrm{~cm}$ ) clayey loams covered wide basaltic benches. Deep $(91 \mathrm{~cm})$ profiles high in pumice sand occurred under rims and formed toeslopes of northeast aspect. Plant nutrients, especially nitrogen, were low in all soils tested.

The climate was cool and dry with prevailing southwest winds. We recorded 28 to $38 \mathrm{~cm}$ of precipitation each year, $80 \%$ of which fell as snow between November and April. Seasonal temperatures ranged from $-28^{\circ} \mathrm{C}$ in winter to $39^{\circ} \mathrm{C}$ in summer and dipped below $0^{\circ} \mathrm{C}$ several times between April and September each year.

Juniper communities formed thermal cover (tree canopy $\geq 25 \%$ ) and cover-forage (tree canopy 5-25\%) habitat components from mule deer and were interspersed with shrubland and grassland forage areas (tree canopy <5\%) (Leckenby 1977, 1978). As recommended by Mueller-Dombois and Ellenberg (1974), the term plant community refers to the sample stand as found in the field and vegetation type and subtype refer to an abstraction of sample stands derived by classification analyses. Clary et al. (1974) used subtype in similar context for Utah juniper (Juniperus osteosperma) and alligator juniper (J. deppeana) in Arizona. Thermal cover was dominated by young (average age $=47 \mathrm{yr}$ ) juniper trees whereas older junipers $>100 \mathrm{yr}$ ) occurred as individuals and groves within the woodland (Adams 1975). Tree canopy varied between $10 \%$ and $45 \%$ among pretreatment communities and was provided by juniper densities of 54 to 282 trees per ha. Shrub understories commonly included mountain big sagebrush (Artemisia tridentata subsp. vaseyana), low sagebrush (Artemisia arbuscula), antelope bitterbrush (Purshia tridentata), lanceleaf green rabbitbrush (Chrysothamnus vicidiflorus subsp. lanceolatus), Truckee green rabbitbrush (Chrysothamnus vicidiflorus subsp. humilis), and gray rabbitbrush (Chrysothamnus nauseosus). Grasses and grass-like plants included bearded bluebunch wheatgrass (Agropyron spicatum), bluestem wheatgrass (Agropyron smithii), Idaho fescue (Festuca idahoensis), Thurber needlegrass (Stipa thurberiana), western needlegrass (Stipa occidentalis), needle and thread (Stipa comata), prairie junegrass (Koeleria cristata), Sandberg bluegrass (Poa sandbergii), Cusick bluegrass (Poa cusickii), bottlebrush squirreltail (Sitanion hystrix), cheatgrass brome (Bromus tectorum), Douglas sedge (Carex douglasii), Ross sedge (Carex rossii), and baltic rush (Juncus balticus). Common forbs were low pussytoes (Antennaria dimorpha), little flower collinsia (Collinsia parviflora), yellow fleabane (Erigeron chrysopsidis), broom buckwheat (Eriogonum vimineum), little buckwheat (Eriogonum strictum), western hawksbeard (Crepis occidentalis), pale agoseris (Agoseris glauca), curvepod loco (Astragalus curvicarpus), Pursh loco (Astragalus purshii), gilia (Gilia sinuata), common starlily (Leucocrinum montanum), bitterroot lewisia (Lewisia redivia), foothill death camas (Zigadenus paniculatus), and microsteris (Microsteris gracilis).

\section{Methods}

We designed the Ward Lake revegetation project to evaluate the influence of treatment, seed mixture, and vegetation subtype on 
success of fall seedings. Treatments comprised chaining and drilling (chain-drill) in 118 ha and drilling under trees (drill-only) in 185 ha. Full-size and half-size rangeland drills (Koehler 1975) were used. Standard crested wheatgrass (Agropyron desertorum) mixtures were planted into $149 \mathrm{ha}$, and Siberian wheatgrass (Agropyron sibericum) mixtures were planted into 154 ha. Seed mixtures emphasizing standard crested wheatgrass were identified with odd number codes, other mixtures emphasizing Siberian wheatgrass were coded with even numbers, and mixtures containing basin big sagebrush (Artemisia tridentata tridentata) were further identified with the letter code $A$ (Tables 1 and 2).

Six juniper vegetation subtypes were derived by cluster analysis of 420 samples of pretreatment plant communities (Table 1). Numerical classification methods adapted to computer processing by Pyott (1972) were used. The subtypes were variations of 4 vegetation types defined by Schallig (1971), and they included maximal differences of plant composition which occurred within juniper types in the study area. Densities of viable seeds (per $\mathrm{m}^{2}$ ) varied among subtypes because of seeding rates $(\mathrm{kg} / \mathrm{ha})$ and germination potential (Table 2). Seeding rates were doubled in the starlily and needle and thread subtypes because their sites were drier than those of the other subtypes.

Treatments and seed mixtures were replicated within each subtype in a balanced, randomized design of 24 experimental units (Table 2). Seeded area in each unit was sampled with a set of 25 randomly distributed $1 \mathrm{~m}^{2}$ plots each year.

Average densities (plants $/ \mathrm{m}^{2}$ ) of seeded species were compared among experimental units in the first, second, and fourth growing seasons $(1972,1973,1975)$. Differences were examined for significance $(p<0.05)$ with the Mann-Whitney U test (Siegel 1956). Seed-

Table 1. Differential plant species, ${ }^{1}$ subtype name, seeded species mixture ${ }^{2}$, and germination percent for 4 subtypes of western juniper vegetation types (Schallig 1971).

\begin{tabular}{ll}
\hline \hline Vegetation type & Differential species \\
\hline Juniperus occidentalis/ & Astragalus filipes \\
Artemisia tridentata & Crepis occidentalis \\
vaseyana/Agropyron & Chaenactis douglasii \\
spicatum-Festuca & Leucocrinum montanum
\end{tabular}

idahoensis

\section{Stipa comata \\ Zigadenus paniculatus}

Needle and thread

Astragalus curvicarpus
Chrysothamnus vicidi

florus humilis

Crepis occidentalis

Erigeron chrysopsidis

Layia glandulosa

Lewisia rediviva

Mentzelia albicaulis

Polemonium micranthum

Carex douglasii

Carex rossii

Koeleria cristata

Oryzopsis hymenoides

Arabis holboellii

Eriophyllum lanatum

Fritillaria atropururea

\begin{abstract}
Agoseris glauca
Chenopodium album

Gilia sinuata

Layia glandulosa

Leucocrinum montanum

Mentzelia albicaulis

Phacelia linearis

Polemonium micranthum
\end{abstract}

Oryzopsis webberi

Penstemon laetus

Phlox spp.
Bitterroot

Subtyp

Douglas sedge

Agoseris

Phlox

\begin{tabular}{lr}
\hline Seed mixture & Seed germin \\
\hline Agropyron desertorum or & 94 \\
A. sibericum & 93 \\
Medicago sativa & 79 \\
Sanguisorba minor & 90 \\
Artemisia tridentata tridentata & 51 \\
Atriplex canescens & 23 \\
Purshia tridentata & 82 \\
Agropyron desertorum or & 94 \\
A. sibericum & 93 \\
Medicago sativa & 79 \\
Sanguisorba minor & 90 \\
Artemisia tridentata tridentata & 51 \\
Atriplex canescens & 23 \\
Purshia tridentata & 82 \\
& \\
Agropyron desertorum or & 90 \\
A. sibericum & 93 \\
Bromus inermis & 88 \\
Elymus junceus & 94 \\
Onobrychis viciaefolia & 48 \\
Sanguisorba minor & 89 \\
Artemisia tridentata tridentata & 51 \\
Purshia tridentata & 82
\end{tabular}

Agropyron desertorum or

A. sibericum 93

Elymus junceus

Medicago sativa $\quad 80$

Onobrychis viciaefolia $\quad 60$

Astragalus cicer $\quad 52$

Artemisia tridentata tridentata 51

Purshia tridentata 82

Agropyron desertorum or $\quad 90$

A. sibericum 93

Bromus inermis $\quad 88$

Elymus junceus $\quad 94$

Onobrychis viciaefolia 48

Sanguisorba minar $\quad 89$

Artemisia tridentata tridentata 51

Purshia tridentata $\quad 82$

Agropyron desertorum or $\quad 90$

A. sibericum 93

Bromus inermis $\quad 88$

Elymus junceus 94

Onobrychis viciaefolia $\quad 48$

Sanguisorba minor $\quad 59$

Artemisia tridentata tridentata 51

Purshia tridentata $\quad 82$

\footnotetext{
'Differential species are, according to Mueller-Dombois and Ellenberg (1974:263), ...the species that permit us to recognize and differentiate vegetation samples in the field as belong ing to any one of the established classes."

${ }^{2}$ Those seed mixtures emphasizing standard crested wheatgrass were identified with odd number codes, other mixtures emphasizing Siberian wheatgrass were coded with even numbers, and mixtures containing basin big sagebrush (Artemisia tridentata tridentata) were further identified with the letter code A.
} 
Table 2. Viable seed densities (seeds $/ \mathrm{m}^{2}$ ) planted within vegetation subtype, treatment method, and seed mixture ${ }^{1}$ categories.

\begin{tabular}{|c|c|c|c|c|c|c|c|c|c|c|c|c|}
\hline \multirow[b]{3}{*}{ Species seeded } & \multicolumn{4}{|c|}{$\begin{array}{c}\text { Starlily and needle and thread } \\
\text { subtypes }\end{array}$} & \multicolumn{4}{|c|}{ Bitterroot, Agoseris, and Phlox subtypes } & \multicolumn{4}{|c|}{ Douglas sedge subtype } \\
\hline & \multicolumn{2}{|c|}{ Chain-drill } & \multicolumn{2}{|c|}{ Drill-only } & \multicolumn{2}{|c|}{ Chain-drill } & \multicolumn{2}{|c|}{ Drill-only } & \multicolumn{2}{|c|}{ Chain-drill } & \multicolumn{2}{|c|}{ Drill-only } \\
\hline & $\operatorname{Mix} 1$ & $\operatorname{Mix} 2 A$ & $\operatorname{Mix} 1$ & $\operatorname{Mix} 2$ & Mix 3A & Mix 4A & Mix 3 & Mix 4 & Mix 5A & Mix $6 \mathrm{~A}$ & $\operatorname{Mix} 5$ & Mix 6 \\
\hline Agropyron desertorum & $394^{2}$ & - & 402 & - & $\begin{array}{c}171,191 \\
192^{3}\end{array}$ & - & $\begin{array}{l}191,191 \\
195\end{array}$ & - & 166 & - & 159 & - \\
\hline Agropyron sibericum & - & 558 & - & 574 & - & $\begin{array}{l}304,271 \\
209\end{array}$ & - & $\begin{array}{l}284,264 \\
264\end{array}$ & - & 210 & - & 230 \\
\hline Bromus inermis & - & - & - & - & $52,57,57$ & $61,55,42$ & $57,57,68$ & 58,5353 & - & - & - & - \\
\hline Elymus junceus & - & - & - & - & $\begin{array}{l}114,126 \\
127\end{array}$ & $\begin{array}{l}137,122 \\
94\end{array}$ & $\begin{array}{l}126,126 \\
130\end{array}$ & $\begin{array}{c}128,119 \\
119\end{array}$ & 110 & 96 & 106 & 105 \\
\hline Medicago sativa & 127 & 126 & 127 & 127 & - & - & - & - & 110 & 96 & 106 & 105 \\
\hline Onobrychis viciaefolia & - & - & - & - & $3,3,3$ & $4,3,2$ & $3,3,3$ & $3,3,3$ & 3 & 3 & 4 & 3 \\
\hline Sanguisorba minor & 13 & 14 & 15 & 15 & $6,7,7$ & $8,7,5$ & $7,7,7$ & $7,6,6$ & - & - & - & - \\
\hline Astragalus cicer & - & - & - & - & - & - & - & - & 54 & 47 & 52 & 51 \\
\hline Artemisia tridentata tridentata & 318 & 302 & - & - & $\begin{array}{l}55,170 \\
173\end{array}$ & $\begin{array}{l}173,166 \\
131\end{array}$ & - & - & 146 & 136 & - & - \\
\hline $\begin{array}{l}\text { Atriplex canescens } \\
\text { Purshia tridentata }\end{array}$ & $\begin{array}{r}11 \\
4\end{array}$ & $\begin{array}{r}11 \\
4\end{array}$ & $\begin{array}{r}11 \\
4\end{array}$ & $\begin{array}{r}11 \\
4\end{array}$ & $\overline{39} 18$ & $\overline{4} 1013$ & $\overline{11} 1118$ & $-\overline{116}$ & - & - & - & - \\
\hline
\end{tabular}

'Those seed mixtures emphasizing standard crested wheatgrass were identified with odd number codes, other mixtures emphasizing Siberian wheatgrass were coded with even numbers, and mixtures containing basin big sagebrush (Artemisia tridentata tridentata) were further identified by adding the letter code $\mathrm{A}$.

${ }^{2}$ Seeding rates were the same in both subtypes.

${ }^{3}$ Different seeding rates and viabilities resulted in seed densities which are listed in the same order as the subtype names.

ing rate, seedling emergence, and wheatgrass establishment specific to the Douglas sedge plant community formed bases of ratios used to evaluate influences of vegetation subtype and seeding rate on plant density within each experimental unit (EU). Emergence and establishment ratios were calculated as follows:

$$
\begin{aligned}
& \text { Ratio }=\frac{\text { density in EUij }}{\text { density in Douglas sedge } E U j} \\
& \text { where: } \\
& \qquad \begin{aligned}
\mathrm{i} & =\text { community } \\
\mathrm{j} & =\text { treatment-seed mixture (the same in both EU's) }
\end{aligned}
\end{aligned}
$$

The average difference between seeding ratios and emergence or establishment ratios was compared for significance by the Willcoxon matched-pairs signed-ranks test (Siegel 1956).

Hyder and Sneva (1954:89) developed a method for rating the success of range seedings which was based on the "... percentage of square foot units stocked by the seeded species." In order to use this method of evaluation we applied regression analyses to data from an adjacent study (Roberts 1975) and derived the following model to convert percentage stocked from square meter plots to percentage stocked for square foot plots:

percentage stocked $=-3.2859+0.4165$ percentage stocked $\left(r^{2}=0.94\right)$ (square foot plots) (square meter plots)

The converted percentage stocked values were used to evaluate seeding success in the second and fourth growing seasons.

\section{Emergence}

\section{Results and Discussion}

Between 4 and $20 \%$ of the viable seeds planted per square meter (Table 2) were observed as seedlings the first growing season. This low proportion of emergence is consistent with results from the seeding of exotic forage species on this ${ }^{2}$ and other rangelands (Cook et al. 1967, Lavin et al. 1973, Hull 1974).

\section{Treatment}

Seedling densities were similar among treatments the first growing season but were generally greater in the drill-only treatment by the second year (Table 3). Plants were small and weak longer in the drill-only treatment, seedling mortality was frequently observed in both treatments, and delayed germination probably was insignificant. Lavin et al. (1973) made similar observations in Arizona, and Cook et al. (1967) found little delayed germination in Utah.

${ }^{2}$ Leckenby, D.A., and D.E. Toweill. (In press). Response of selected plant species seeded on mule deer winter range. J. Range Manage.

\section{Seed Mixture}

Neither seed mixture consistently produced more seedlings than the other. The few differences suggested that the standard crested wheatgrass mixture resulted in more emergence than did the Siberian wheatgrass mixture (Table 3). Earlier tests also indicated greater emergence and establishment of standard crested wheatgrass in the study area.

\section{Vegetation Subtype}

Vegetation subtype was significantly $(p<0.01)$ rclated to seedling density in the first growing season (emergence), and became more pronounced by the second. Consistently, fewer seedlings were found in the Douglas sedge subtype than in the other 5 subtypes. Differences in emergence among vegetation subtypes were greater than differences in seeding rates between subtypes.

\section{Establishment}

Plants were considered established when their roots could not be pulled out of the soil (Cook et al. 1967). On this basis, only 2 wheatgrass species successfully established stands. Standard crested wheatgrass and Siberian wheatgrass established densities greater than 5 plants $/ \mathrm{m}^{2}$ in the second growing season in chaindrill treatments; establishment remained at that level until the fourth growing season except in the Douglas sedge subtype. Whea tgrass densities were less than 5 plants $/ \mathrm{m}^{2}$ in drill-only units. Combined densities of all other seeded species averaged less than 2 plants $/ \mathrm{m}^{2}$ in both treatments. Similar responses among species have been observed elsewhere (Cook 1966, Lavin et al. 1973, Hull 1974, Drawe et al. 1975, Roberts 1975).

\section{Treatment}

Chain-drill treatments produced greater densities of standard crested wheatgrass and Siberian wheatgrass than did drill-only treatments (Table 4). Wheatgrass densities declined between the second and fourth growing seasons in both treatments. Our results were comparable with similar treatments in communities of the lower pinyon-juniper zone in Colorado (Hull and Doran 1950) and in Utah (Cook 1966).

Cook et al. (1967) found most plants became established in the third growing season. Plants in our chain-drill treatment became sufficiently established during the second year to survive intense grazing the next April. Although plants in the drill-only treatment were established by the third growing scason, their stems were thin, short, and easily pulled from the plant crown. 
Table 3. Average number of seedlings $/ \mathrm{m}^{2}$ compared for treatment method and seed mixture effects within growing seasons and vegetation subtypes.

\begin{tabular}{|c|c|c|c|c|c|}
\hline \multirow[b]{2}{*}{ Vegetation subtype } & \multirow[b]{2}{*}{ Growing season } & \multicolumn{2}{|c|}{ Chain-drill Treatment } & \multicolumn{2}{|c|}{ Drill-only Treatment } \\
\hline & & $\begin{array}{l}\text { Standard crested } \\
\text { wheatgrass } \\
\text { seed mixture }\end{array}$ & $\begin{array}{l}\text { Siberian } \\
\text { seed mixture }\end{array}$ & $\begin{array}{l}\text { Standard crested } \\
\text { wheatgrass } \\
\text { seed mixture }\end{array}$ & $\begin{array}{l}\begin{array}{l}\text { Siberian } \\
\text { seed mixture }\end{array} \\
\end{array}$ \\
\hline Starlily & $\begin{array}{l}1 \\
2\end{array}$ & $\begin{array}{c}37.1 \\
9.1^{\text {a1 }}\end{array}$ & $\begin{array}{l}44.2 \\
12.8^{b}\end{array}$ & $\begin{array}{l}48.5 \\
17.5^{\mathrm{ac}}\end{array}$ & $\begin{array}{l}42.6 \\
25.8^{\mathrm{bc}}\end{array}$ \\
\hline Needle and thread & $\begin{array}{l}1 \\
2\end{array}$ & $\begin{array}{c}33.2 \\
8.6^{\mathrm{a}}\end{array}$ & $\begin{array}{r}43.7 \\
8.3^{b}\end{array}$ & $\begin{array}{l}51.9 \\
33.6^{\mathrm{ac}}\end{array}$ & $\begin{array}{l}40.8 \\
21.2^{b c}\end{array}$ \\
\hline Bitterroot & $\begin{array}{l}1 \\
2\end{array}$ & $\begin{array}{l}34.2^{\mathrm{a}} \\
12.8^{\mathrm{ab}}\end{array}$ & $\begin{array}{r}17.7^{\mathrm{ab}} \\
7.7^{\mathrm{bc}}\end{array}$ & $\begin{array}{l}26.6 \\
21.5^{\text {ad }}\end{array}$ & $\begin{array}{l}29.2^{\mathrm{b}} \\
30.1^{\mathrm{cd}}\end{array}$ \\
\hline Douglas sedge & $\begin{array}{l}1 \\
2\end{array}$ & $\begin{array}{l}11.1 \\
1.6^{\mathrm{a}}\end{array}$ & $\begin{array}{r}11.4 \\
2.0\end{array}$ & $\begin{array}{l}12.7 \\
6.0^{\mathrm{ab}}\end{array}$ & $\begin{array}{c}12.5 \\
3.9^{\mathrm{b}}\end{array}$ \\
\hline Agoseris & $\begin{array}{l}1 \\
2\end{array}$ & $\begin{array}{r}33.3 \\
6.4^{\mathrm{a}}\end{array}$ & $\begin{array}{r}29.6 \\
6.6^{\mathrm{b}}\end{array}$ & $\begin{array}{l}18.2 \\
20.8^{\mathrm{a}}\end{array}$ & $\begin{array}{l}23.8 \\
15.9^{b}\end{array}$ \\
\hline Phlox & $\begin{array}{l}1 \\
2\end{array}$ & $\begin{array}{r}28.1^{\mathrm{a}} \\
3.8^{\mathrm{a}}\end{array}$ & $\begin{array}{r}16.8^{\mathrm{a}} \\
5.4^{\mathrm{b}}\end{array}$ & $\begin{array}{l}32.7^{\mathrm{b}} \\
15.4^{\mathrm{a}}\end{array}$ & $\begin{array}{l}20.4^{b} \\
12.5^{b}\end{array}$ \\
\hline
\end{tabular}

Treatment or seed mixture response compared while subtype and season held constant. Like superscript letters indicate significant differences between treatments or seed mixtures within a row at $\alpha=0.05$.

\section{Seed Mixture}

Standard crested wheatgras tended to maintain greater densities than Siberian wheatgrass in all but the starlily chain-drill experimental units; few differences were significant (Table 4). In contrast, establishment of Siberian wheatgrass was significantly greater than that of standard crested wheatgrass in the Nine Mile Ridge project, $8 \mathrm{~km}$ (5 mi) to the north (Roberts 1975).

\section{Vegetation Subtype}

Vegetation subtypes appeared related to rate of establishment of standard crested wheatgrass and Siberian wheatgrass in both chain-drill and drill-only treatments. Such an effect was indicated both years and was most apparent in the chain-drill treatments (Table 4). Plant densities in both years declined generally in the following order of subtypes: starlily, needle and thread, agoseris, bitterroot, phlox, and Douglas sedge. Drill-only, Siberian wheatgrass experimental units were the major exception to this order. Densities of wheatgrass in the starlily and needle and thread subtypes exceeded those in the Douglas sedge subtype on the average by factors of 5.7 and 6.2 in the second growing season but by only
4.1 and 5.6 in the fourth growing season (Table 4). Seeding rates in those subtypes differed by a factor of only 2.5 (Table 2). Densities in the bitterroot, agoseris, and phlox subtypes exceeded those in the Douglas sedge subtype by factors of $4.1,3.4$, and 2.4 , respectively, in the second growing season and by only $5.4,2.3$, and 1.6 in the fourth growing season (Table 4). Average seeding rates in the bitterroot, agoseris, and phlox subtypes exceeded those in the Douglas sedge subtype by a factor of only 1.2 (Table 2).

The magnitude of differences of wheatgrass establishment generally followed the degree of difference in species composition between vegetation subtypes. During cluster analysis, differences in species composition were quantified by calculation of Euclidean distance (Pyott 1972). Correlation a nalyses suggested that absolute differences in densities, both as measured (Table 4) and as adjusted for comparable seeding rates were directly proportional to squared Euclidean distance (Table 5). Sample sizes, however, were not sufficient for testing of statistical significance.

\section{Success}

Standard crested wheatgrass and Siberian wheatgrass estab-

Table 4. Average wheatgrass densities ${ }^{1}$ (plants $/ \mathrm{m}^{2}$ ) compared for treatment, seed mixture, or vegetation subtype effects within the second and fourth growing seasons.

\begin{tabular}{|c|c|c|c|c|c|c|c|c|c|}
\hline \multirow[b]{3}{*}{$\begin{array}{l}\text { Vegetation subtype and } \\
\text { growing season }\end{array}$} & & \multicolumn{4}{|c|}{ Chain-drill treatment } & \multicolumn{4}{|c|}{ Drill-only Treatment } \\
\hline & & \multicolumn{2}{|c|}{ Standard crested wheatgrass } & \multicolumn{2}{|c|}{ Siberian wheatgrass } & \multicolumn{2}{|c|}{ Standard crested wheatgrass } & \multicolumn{2}{|c|}{ Siberian wheatgrass } \\
\hline & & $\overline{\mathbf{x}}$ & Differences & $\overrightarrow{\mathbf{X}}$ & Differences & $\bar{x}$ & Differences & $\bar{x}$ & Differences \\
\hline Starlily & $\begin{array}{l}2 \\
4\end{array}$ & $\begin{array}{l}20.2^{\mathrm{a} 2} \\
12.3^{\mathrm{a}}\end{array}$ & $\begin{array}{l}\text { B,D,P } \\
\text { B,D,P }\end{array}$ & $\begin{array}{l}20.4^{\mathrm{b}} \\
13.6^{\mathrm{b}}\end{array}$ & $\begin{array}{l}\text { A,B,D,P } \\
\text { A,B,D,P }\end{array}$ & $\begin{array}{l}4.8^{\mathrm{ac}} \\
2.1^{\mathrm{ac}}\end{array}$ & $A, D, N, P$ & $\begin{array}{l}0.0^{\mathrm{bc}} \\
0.4^{\mathrm{bc}}\end{array}$ & $\begin{array}{l}\mathrm{B}, \mathrm{N} \\
\mathrm{B}, \mathrm{N}\end{array}$ \\
\hline Needle and thread & $\begin{array}{l}2 \\
4\end{array}$ & $\begin{array}{l}17.5^{\mathrm{a}} \\
11.6^{\mathrm{a}}\end{array}$ & $\begin{array}{l}\text { B,D,P } \\
\text { B,D,P }\end{array}$ & $\begin{array}{r}22.4^{\mathrm{b}} \\
9.4^{\mathrm{b}}\end{array}$ & $\begin{array}{l}\text { A,B,D,P } \\
\text { A,B,D,P }\end{array}$ & $\begin{array}{l}1.8^{\mathrm{a}} \\
2.7^{\mathrm{a}}\end{array}$ & $\begin{array}{l}\text { A.D.S } \\
\text { D.P }\end{array}$ & $\begin{array}{l}1.3^{\mathrm{b}} \\
1.8^{\mathrm{b}}\end{array}$ & $\begin{array}{l}\text { A,D,S } \\
\text { A,B,D,P,S }\end{array}$ \\
\hline Bitterroot & $\begin{array}{l}2 \\
4\end{array}$ & $\begin{array}{l}9.8^{\mathrm{a}} \\
7.4^{\mathrm{ab}}\end{array}$ & $\begin{array}{l}A, D, N, S \\
D, N, S\end{array}$ & $\begin{array}{l}6.7^{\mathrm{b}} \\
4.1^{\mathrm{b}}\end{array}$ & $\begin{array}{l}\text { A,D,N,S } \\
\mathrm{D}, \mathbf{N}, \mathbf{S}\end{array}$ & $\begin{array}{l}2.8^{\mathrm{ac}} \\
1.6^{\mathrm{ac}}\end{array}$ & $A, D, P$ & $\begin{array}{l}1.2^{\mathrm{bc}} \\
2.8^{\mathrm{c}}\end{array}$ & $\begin{array}{l}\text { S } \\
A, D, N, P, S\end{array}$ \\
\hline Douglas sedge & $\begin{array}{l}2 \\
4\end{array}$ & $\begin{array}{l}2.6^{\mathrm{a}} \\
3.2^{\mathrm{ab}}\end{array}$ & $\begin{array}{l}A, B, N, P, S \\
A, B, N, P, S\end{array}$ & $\begin{array}{l}2.5^{\mathrm{b}} \\
2.1^{\mathrm{bc}}\end{array}$ & $\begin{array}{l}\text { A,B,N,P,S } \\
A, B, N, P, S\end{array}$ & $\begin{array}{l}0.7^{\mathrm{a}} \\
0.5^{\text {ad }}\end{array}$ & $\begin{array}{l}\mathrm{B}, \mathbf{N}, \mathbf{S} \\
\mathbf{N}\end{array}$ & $\begin{array}{l}0.2^{\mathrm{b}} \\
0.2^{\text {od }}\end{array}$ & $\begin{array}{l}\mathbf{N} \\
\mathbf{B}, \mathbf{N}\end{array}$ \\
\hline Agoseris & $\begin{array}{l}2 \\
4\end{array}$ & $\begin{array}{c}18.7^{\mathrm{ab}} \\
8.9^{\mathrm{a}}\end{array}$ & $\begin{array}{l}\mathrm{B}, \mathrm{D}, \mathbf{P} \\
\mathrm{D}\end{array}$ & $\begin{array}{c}12.3^{\mathrm{bc}} \\
6.0^{\mathrm{b}}\end{array}$ & $\begin{array}{l}\text { B,D,N,S,P } \\
\mathrm{D}, \mathbf{N}, \mathbf{S}\end{array}$ & $\begin{array}{l}0.6^{\mathrm{a}} \\
1.1^{\mathrm{a}}\end{array}$ & B,N,S,P & $\begin{array}{l}0.1^{c} \\
0.3^{b}\end{array}$ & $\begin{array}{l}\mathrm{N} \\
\mathrm{B}, \mathrm{N}\end{array}$ \\
\hline Phlox & $\begin{array}{l}2 \\
4\end{array}$ & $\begin{array}{l}9.4^{a} \\
5.7^{a}\end{array}$ & $\begin{array}{l}\text { A,D,N,S } \\
\text { D,N,S }\end{array}$ & $\begin{array}{l}7.6^{\mathrm{b}} \\
4.0^{\mathrm{b}}\end{array}$ & $\begin{array}{l}\text { A,D,N,S } \\
\mathrm{D}, \mathrm{N}, \mathrm{S}\end{array}$ & $\begin{array}{l}1.1^{\mathrm{ac}} \\
0.6^{\mathrm{a}}\end{array}$ & $\begin{array}{l}\mathbf{A}, \mathbf{B}, \mathbf{S} \\
\mathrm{N}\end{array}$ & $\begin{array}{l}0.3^{b c} \\
0.3^{b}\end{array}$ & $\mathbf{B}, \mathbf{N}$ \\
\hline
\end{tabular}

'Density of Agropyron desertorum or Agropyron sibericum.

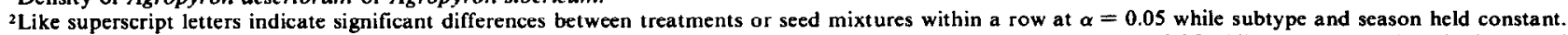

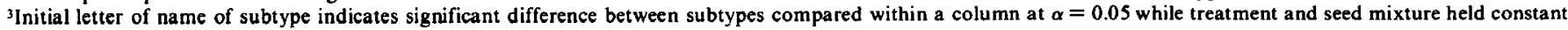



Table 5. Correlation coefficients for absolute difference in establiched plant density verus degreel of vegetation subtype difference within growing season,
treatment, and wheatgrass categories.

\begin{tabular}{|c|c|c|c|c|}
\hline \multirow[b]{2}{*}{ Growing season } & \multirow[b]{2}{*}{ Treatment } & \multirow[b]{2}{*}{ Wheatgrass } & \multicolumn{2}{|c|}{ Correlation coefficient } \\
\hline & & & $\begin{array}{l}\text { Differences in subtype } \\
\text { density as measured }\end{array}$ & $\begin{array}{c}\text { Differences in subtype } \\
\text { density adjusted for } \\
\text { seeding rate }\end{array}$ \\
\hline 2 & $\begin{array}{l}\text { Chain-drill } \\
\text { Drill-only }\end{array}$ & $\begin{array}{l}\text { standard crested } \\
\text { Siberian } \\
\text { standard crested } \\
\text { Siberian }\end{array}$ & $\begin{array}{r}0.44 \\
0.56 \\
-0.09 \\
0.01\end{array}$ & $\begin{array}{l}0.56 \\
0.81 \\
0.58 \\
0.63\end{array}$ \\
\hline 4 & $\begin{array}{l}\text { Chain-drill } \\
\text { Drill-only }\end{array}$ & $\begin{array}{l}\text { standard crested } \\
\text { Siberian } \\
\text { standard crested } \\
\text { Siberian }\end{array}$ & $\begin{array}{r}0.87 \\
-0.70 \\
0.92 \\
0.68\end{array}$ & $\begin{array}{r}0.84 \\
-0.58 \\
0.99 \\
0.89\end{array}$ \\
\hline
\end{tabular}

'Degree of vegetative difference among subtypes was assessed by an index of dissimilarity, i.e., squared Euclidean distance (Pyott 1972).

lished fair to poor grass stands and the other 9 plant species failed to establish. Percentage stocking (Hyder and Sneva 1954) of wheatgrass varied from 0 to $38 \%$ in the second and fourth growing seasons (Table 6). Hyder and Sneva (1954:89) recognized that success ratings assigned to specific percentage-stocked levels should vary with site conditions and seeding objectives. Their criteria do allow comparison with seedings designed to increase livestock forage in other types. Judgement of success of this project for deer, however, must await correlation of percentage-stocked levels with declining cover amounts as well as increasing forage production.

The failure of all species but wheatgrass was similar to results from an associated study in Oregon (Roberts 1975) and other research in Arizona, Colorado, New Mexico, and Utah (McGinnies 1960, Aro 1971, Lavin et al. 1973, Drawe et al. 1975). The densities of established plants in this study were frequently less than observed in pinyon-juniper conversions in Utah and Arizona (Cook 1966, Lavin et al. 1973, Drawe et al. 1975).

\section{Conclusion}

Juniper manipulation and forage seeding have been used to rehabilitate depleted winter ranges of mule deer and spring ranges of livestock throughout the intermountain west. Results of this study in the western juniper zone were similar to some treatments of other juniper types. The chain-drill treatment successfully converted winter-cover areas into spring-forage areas and, the drillonly treatment provided small amounts of additional spring forage but without disrupting cover. Winter forage supplies were not increased in either treatment. Since the principal use of juniper thermal cover by deer occurred over winter and use of grassland forage arcas was high in spring, the net effect on the mule deer population of converting cover areas into forage areas was unknown.

Plummer et al. (1968) recommended mixtures of seed to increase chances for establishment of some plant cover when seeding several sites. Essentially, only crested wheatgrass and Siberian wheatgrass survived in several of our projects that included aerial

Table 6. Percentage stocked ${ }^{1}$ and success rating ${ }^{2}$ of grass stands from seeding crested wheatgrass and Siberian wheatgrass by western juniper subtype, treatment, and growing season categories.

\begin{tabular}{|c|c|c|c|c|c|c|}
\hline \multirow[b]{2}{*}{ Vegetation subtype } & \multirow[b]{2}{*}{ Treatment } & \multirow[b]{2}{*}{ Growing season } & \multicolumn{2}{|c|}{ Standard crested wheatgrass } & \multicolumn{2}{|c|}{ Siberian wheatgrass } \\
\hline & & & Percentage stocked & Success rating & Percentage stocked & Success rating \\
\hline Starlily & $\begin{array}{l}\text { Chain-drill } \\
\text { Drill-only }\end{array}$ & $\begin{array}{l}2 \\
4 \\
2 \\
4\end{array}$ & $\begin{array}{l}37 \\
37 \\
30 \\
17\end{array}$ & $\begin{array}{c}\text { fair } \\
\text { fair } \\
\text { fair } \\
\text { poor }\end{array}$ & $\begin{array}{r}38 \\
35 \\
0 \\
5\end{array}$ & $\begin{array}{l}\text { fair } \\
\text { fair } \\
\text { failure } \\
\text { failure }\end{array}$ \\
\hline Needle and thread & $\begin{array}{l}\text { Chain-drill } \\
\text { Drill-only }\end{array}$ & $\begin{array}{l}2 \\
4 \\
2 \\
4\end{array}$ & $\begin{array}{l}38 \\
37 \\
23 \\
20\end{array}$ & $\begin{array}{l}\text { fair } \\
\text { fair } \\
\text { poor } \\
\text { poor }\end{array}$ & $\begin{array}{l}38 \\
38 \\
13 \\
18\end{array}$ & $\begin{array}{l}\text { fair } \\
\text { fair } \\
\text { poor } \\
\text { poor }\end{array}$ \\
\hline Bitterroot & $\begin{array}{l}\text { Chain-drill } \\
\text { Drill-only }\end{array}$ & $\begin{array}{l}2 \\
4 \\
2 \\
4\end{array}$ & $\begin{array}{l}38 \\
38 \\
28 \\
20\end{array}$ & $\begin{array}{l}\text { fair } \\
\text { fair } \\
\text { fair } \\
\text { poor }\end{array}$ & $\begin{array}{l}35 \\
30 \\
12 \\
30\end{array}$ & $\begin{array}{l}\text { fair } \\
\text { fair } \\
\text { poor } \\
\text { fair }\end{array}$ \\
\hline Douglas sedge & $\begin{array}{l}\text { Chain-drill } \\
\text { Drill-only }\end{array}$ & $\begin{array}{l}2 \\
4 \\
2 \\
4\end{array}$ & $\begin{array}{l}30 \\
27 \\
12 \\
17\end{array}$ & $\begin{array}{l}\text { fair } \\
\text { fair } \\
\text { poor } \\
\text { poor }\end{array}$ & $\begin{array}{r}27 \\
15 \\
2 \\
2\end{array}$ & $\begin{array}{l}\text { fair } \\
\text { poor } \\
\text { failure } \\
\text { failure }\end{array}$ \\
\hline Agoseris & $\begin{array}{l}\text { Chain-drill } \\
\text { Drill-only }\end{array}$ & $\begin{array}{l}2 \\
4 \\
2 \\
4\end{array}$ & $\begin{array}{c}37 \\
37 \\
5 \\
13\end{array}$ & $\begin{array}{c}\text { fair } \\
\text { fair } \\
\text { failure } \\
\text { poor }\end{array}$ & $\begin{array}{r}38 \\
32 \\
2 \\
5\end{array}$ & $\begin{array}{l}\text { fair } \\
\text { fair } \\
\text { failure } \\
\text { failure }\end{array}$ \\
\hline Phlox & $\begin{array}{l}\text { Chain-drill } \\
\text { Drill-only }\end{array}$ & $\begin{array}{l}2 \\
4 \\
2 \\
4\end{array}$ & $\begin{array}{l}37 \\
30 \\
18 \\
12\end{array}$ & $\begin{array}{l}\text { fair } \\
\text { fair } \\
\text { poor } \\
\text { poor }\end{array}$ & $\begin{array}{r}35 \\
33 \\
3 \\
5\end{array}$ & $\begin{array}{l}\text { fair } \\
\text { fair } \\
\text { failure } \\
\text { failure }\end{array}$ \\
\hline
\end{tabular}

'Percentage stocked is defined as the pereent of $0.093 \mathrm{M}^{2}$ plots that contained a species of interest (Hyder and Sneva 1954).

${ }^{2}$ These ratings were developed for livetock ranges with $3.9-4.7 \mathrm{~cm}$ of annual precipitation (Hyder and Sneva 1954). 
seedings. Inclusion of seeds of other grasses, forbs, and shrubs in the mixtures appears to be of questionable value for plantings in the western juniper zone.

Pretreatment vegetation subtypes may aid managers to predict responses from manipulation. In this study, variations of species composition among 6 western juniper subtypes were associated with differences of emergence, establishment, and survival of 2 wheatgrasses commonly used in range improvement projects.

\section{Literature Cited}

Adams, A.W. 1975. A brief history of juniper and shrub populations in southem Oregon. Oregon State Wildl. Comm. Wildl. Res. Rep. 6. Res. Div., Corvallis.

Aro, R.S. 1971. Evaluation of pinyon-juniper conversion to grassland. J. Range Manage. 24:188-197.

Clary, W.P., M.B. Baker, Jr., P.F. O'Connell, T.N. Johnsen, Jr., and R.E. Campbell. 1974. Effects of pinyon-juniper removal on natural resource products and uses in Arizona. USDA-FS Res. Pap. RM-128. Rocky Mountain Forest and Range Exp. Sta., Fort Collins, Colo.

Cook C.W. 1966. Development and use of foothill ranges in Utah. Utah Agr. Exp. Sta. Bull. 461. Utah State Univ., Logan.

Cook, C.W., L.A. Stoddart, and P.L. Simms. 1967. Effects of season, spacing, and intensity of seeding on the development of foothill range grass stands. Utah Agr. Exp. Sta. Bull. 467. Utah State Univ., Logan.

Drawe, D.L., J.B. Grumbles, and J.F. Hooper. 1975. Establishment of Russian wildrye on foothill ranges in Utah. J. Range Manage. 28:152154.

Garrison, G.A., J.M. Skovlin, C.E. Poulton, and A.H. Winward. 1976. Northwest plant names and symbols for ecosystem inventory and analysis. Fourth Edition. USDA-FS Gen. Tech. Rep. PNW-46. Pacific Northwest Forest and Range Exp. Sta., Portland, Ore.

Hull, A.C. Jr. 1974. Seed ling emergence and survival from different seasons and rates of seeding mountain rangeland. J. Range Manage. 27:302-304.

Hull, A.C., and C.W. Doran. 1950. Preliminary guide to reseeding pinyonjuniper lands of western Colorado. USDA-FS Sta. Pap. No. 4. Rocky Mountain Forest and Range Exp. Sta., Fort Collins, Colo.

Hyder, D.N., and F.A. Sneva. 1954. A method for rating the success of range seedings. J. Range Manage. 7:89-90.
Koehler, D.A. 1975. A review of the literature on reseeding sagebrushbunchgrass ranges in the semi-arid western United States. Oregon Wildl. Comm. Wildl. Res. Rep. 4. Res. Div., Corvallis.

Lavin, F., F.B. Gomm, and T.N. Johnson, Jr. 1973. Cultural, sea sonal and site effects on pinyon-juniper rangeland plantings. J. Range Manage. 26:279-285.

Leckenby, D.A. 1977. Management of mule deer and their habitat: applying concepts of behavior, physiology, and microclimate. Proc. Western Assoc. State Game and Fish. Comm. 57:206-217.

Leckenby, D.A. 1978. Western juniper management for mule deer. p. 137-161. In: Proceedings Western Juniper Ecology and Management Workshop, (eds.) R.E. Martin, J.E. Dealy, and D.L. Caraher. USDAFS Gen. Tech. Rep. PNW-74. Pacific Northwest Forest and Range Exp. Sta., Portland, Ore.

McGinnies, W.J. 1960. Effects of planting dates, seeding rates, and row spacings on range seeding results in western Colorado. J. Range Manage. 13:37-39.

Mueller-Dombois, D., and H. Ellenberg. 1974. Aims and methods of vegetation ecology. John Wiley and Sons. New York.

Plummer, A.P., D.R. Christensen, and S.B. Monsen. 1968. Restoring big-game range in Utah. Utah Div. Fish and Game Pub. 68-3. Salt Lake City.

Pyott, W.T. 1972. Numerical classification of range vegetation and statistical analysis of its ecology. Ph.D. Thesis. Oregon State Univ., Corvallis.

Roberts, R.W. 1975. Silver Lake mule deer research: utilization of Nine Mile Ridge seeding by mule deer and compilation, analysis, interpretation, and publication of data acquired on Nine Mile Ridge sceding success. Oregon Dep. Fish and Wildl. Job Completion Rep. W-70-R-1 through 5, Sub B. SIIJ4 and 7, 35 p. Portland.

Schallig, W.H.C. 1971. Key to Silver Lake mule deer winter range plant communities. p. 13-24. In: Mule Deer Winter Range Ecology and Management: Data Analysis, Interpretation, and Publication. D.A. Leckenby and A.W. Adams Oregon State Game Comm. Job Prog. Rep. W-70-R-1 Sub B. SIJ5. Corvallis.

Siegel, S. 1956. Nonparametric statistics for the behavioral sciences. McGraw-Hill Book Co., Inc., New York.

Winegar, H., and W. Elmore. 1978. Mechanical manipulation of western juniper-some methods and results. p. 107-119. In: Proceedings of the Western Juniper Ecology and Management Workshop, edited by R.E. Martin, J.E. Dealy, and D.L. Caraher. USDA-FS. Gen. Tech. Rep. PNW-74. Pacific Northwest Forest and Range Exp. Sta., Portland, Ore.

\section{Don't miss the 1984 Annual Meeting of the Society for Range Management February 12-17, 1984 in Rapid City, South Dakota}

